\title{
REVIEW OF SUSTAINABLE BUSINESS AND PROFITABILITY OF ECO-FRIENDLY HOTELS IN SERBIA
}

\author{
Milovan Stanišić \\ Nikica Radović*, \\ Jelena Nikolić
}

Singidunum University, Belgrade, Serbia

\begin{abstract}
:
Considering contemporary global existence, it is necessary for a so-ciety to function in accordance with the ecological capabilities of its climate and natural environment, and this very attitude forms the so - called understanding and the theorem on sustainable development. The term sustainable development refers to the overall development of society, from the aspect of economic, social, ecological and technological development, harmonized with the quality of the environment and environmental protection. Namely, in order to consider sustainable development in tourism and ecologically responsible business, the paper will examine the ecological activities that hotels carry out while providing accommodation and catering services to guests. It will also examine the criteria included in the Green Key label, on a sample of hotels that do business in Serbia. What is more, in this paper we will present the analysis results of profitability indicators of the analyzed hotels for the business period in 2017 and 2018.
\end{abstract}

\section{Keywords:}

sustainable development, eco-hotel, Green Key, circular economy, profitability indicators

\section{INTRODUCTION}

Considering the segments of defining sustainable development, which are based on the preservation and protection of the environment and the quality of environment, both for the needs of modern society and for future generations in this area, it is necessary to analyze the activities and application of standards in the economic entities operating within them in each country respectively. In this regard, sustainable tourism development is a concept of development that should balance ecological, economic, socio-cultural and technological components in the tourist destination, at the tourists' satisfaction.

According to UNEP \& UNWTO (UNWTO, 2005), "sustainable tourism" is the tourism that fully takes into account present and future, economic, social and ecological impact, meeting the needs of visitors, industry, environment and the community. Therefore, sustainable tourism should promote the optimal use of environmental resources, and ensure long-term sustainability, with economic activities and benefits provided to all the interested parties in a particular climate.

The UN Conference on the Environment and Sustainable Development was held in Rio de Janeiro in 1992 and, as a result, Agenda 21 was adopted as a development plan for the next century, with the aim to apply seventeen sustainable development principles. In this regard, the Agenda 21 for the Tourism Economy was adopted by the World Tourism and Trade Council (Dražić, 2018) in 1996. 
This document defines twelve goals of the tourism sustainable development, with a view to the economic prosperity of tourism, with the indispensable principles of environmental protection, biodiversity, conservation of landscapes and resource efficiency. The economic entities, which operate in the field of tourism activities and movement, as well as accommodation and catering services, are expected to achieve the set goals by focusing primarily on environmental protection activities through waste management, energy management, energetic efficiency, drinking and waste water management, harmful materials management and employee education.

Circular economy is emerging as an important field in modern society. In order to achieve the goals of sustainable development, it is developing activities and long-term investments in raw materials and energy efficiency, with the replacement of non-renewable fuels with renewable ones, reduction of harmful gases and substances emission, formation of the "product - waste - product" circle, and sustainable products production and trade.

As one of sustainable business segments, eco-responsible business in the hospitality industry is based on activities that include: energy management, energetic efficiency, waste management, environmental management, drinking and waste water management, with continuous education of employees regarding their knowledge and skills about the mentioned activities in business processes.

\section{LITERATURE REVIEW}

Sustainable tourism social and economic aspects are inextricably linked to eco-responsible business segments of all participants in the tourism industry. Hotel, i.e. accommodation capacities are considered to be the key segments, bearing in mind the nature of their activity and the importance they have as a sub-industry in the tourism industry entire system. According to the Statista portal data (Dec.2018), global hospitality industry revenue in 2017 was 570.18 trillion US dollars, and the industry itself was recognized as one of the largest consumers of electricity and pollution in the environment, i.e. at the destination where they did business.

Kirk (1995) found that hotel companies in UK complied with sustainable hotel policies mainly in environmental segments, due to direct cost reductions in waste and electricity management business. Camilleri (2014) analyzed a large number of authors who investigated the relationship between responsibility and business performance and confirmed that a positive correlation was observed in a large number of activity studies and parameters related to socially responsible business and financial performance within the analyzed results of hotel corporation business. There are a number of internal reasons
- financial indicators of business and external reasons - environmental impact and sustainability of the tourist destination, which have resulted in increased involvement of hotel companies in the sphere of ecologically sustainable business and circular economy. In this regard, there are defined standards, guidelines and criteria at the global level that certain hotel companies must meet in order to be considered eco-friendly from the social aspect.

The Foundation for Environmental Education (FEE), based in Copenhagen (Denmark), has 77 member states and promotes sustainable development through environmental education, with a non-profit goal, through its programs: Blue Flag, Green Key, Eco School, Young Reports and Learning about Forests. A significant program, in terms of hotel business, is certainly Green Key. Green Key is an eco-label for the facilities of the suprastructure in the tourism industry which is based on 13 different areas of criteria that must be met according to different types of facilities - hotels and hostels, camps and amusement parks, small accommodation facilities, conference and convention centers, restaurants. The criteria are based on activities which cover the following areas: Corporate Social Responsibility (CSR), environmental facilities maintenance, ecologically sustainable facility operations, energy and water management in facilities, management of various types of waste, equipping and maintaining accommodation units, food and drinks preparation, employee education. The holders of this designation agree with their guests to apply all the standards related to ecologically responsible business and environmental protection.

Some of the binding criteria are that the total consumption of water and electricity must be monitored on a monthly basis. After flushing, toilets must not consume more than 6 litres of water, water flow in showers must not exceed 9 litres per minute, while faucet water flow is recommended to be 8 litres per minute. Dishwashers must not use more than 3.5 litres per basket, and all wastewater must be treated in accordance with local and national legislation. Chemicals and disinfectants are used only when needed and must have an eco-label, i.e. must not contain any of the ingredients from the so-called "Black list". Paper goods used e.g. towels, paper, etc. must be made of chlorine-free white paper with some eco-label. It is necessary to monitor waste management through the processes of proper waste selection while harmful substances (solid or liquid) must be separated in safety containers. Air conditioning and heating must be serviced according to seasonal needs. It is necessary to use energy efficient LED bulbs for $75 \%$ of the lighting and it is preferable to use an automatic i.e. sensor lighting. There are other criteria in addition to these established criteria, and most of them are imperative and must be implemented in accordance with the rules, while other criteria are guidelines that must be met depending on the year of inclusion in the Green Key program. 
When it comes to the representation of objects in the world, Green Key label is used in 57 countries, in 3100 different types of objects. The situational analysis of these designation holders in countries is as follows: in the Netherlands 689, France 624, Greece 343, Belgium 235, Portugal 180. Mexico 161, Sweden 144, Denmark 143, Germany 42, Norway 30, and Serbia ranks 33rd with 4 hotel facilities. All four facilities in Serbia are four-star hotels and three are located in an urban setting while one is in a mountain center.

\section{METHODOLOGY}

The aim of this paper is to examine and evaluate sustainable business performance of four - star hotels that have Green Key eco - labels in Serbia in terms of their business profitability. In this regard, the analysis of scientific literature and secondary data has been done. For the purpose of calculating profitability indicators, it was necessary to use the data from financial statements for business years 2017 and 2018 of the analyzed companies, which operate in the field of Accommodation and catering service - 5510. Furthermore, facts about ecologically responsible business of the analyzed hotels were presented, on the basis of research conducted by desk research method, and available materials on their business.

\section{RESEARCH RESULTS}

While forming the analysis sample, some limitations appeared. One of the hotels in Serbia, which bears the Green Key label, does not have a business activity code 5510 - Accommodation and catering service as its field of activity in financial statements - but operates as a branch of a company that is predominantly engaged in other activities, so it was eliminated from the sample. Therefore, the analysis of profitability indicators and research into the application of ecological liability criteria were examined through business of the other three hotels (hereinafter referred to as Hotel A, B, C).

In accordance with the defined Green Key criteria, we have considered the application of a certain group of criteria in the business of sampled hotels, and the obtained results are reviewed, consolidated and further presented. Taking into account energy efficiency segments and the criteria that must or should be fulfilled, hotels use standard electricity as well as renewable energy sources. They also use key cards for the roomswhich makes it possible to regulate energy in the accommodation units. Hotel B implements solar system panels for heating sanitary water, swimming pool water and surrounding area, while Hotel $\mathrm{C}$ implements a geothermal heating and cooling system.
All facilities use 100\% LED lighting and have motion sensors that save energy significantly. Energy efficiency is necessary when constructing new facilities in Serbia since having the so - called "energy passports" for the facility makes it possible to achieve energy and financial savings in business (Barjaktarović et al., 2017).

Chart 1. Overview of the application of eco - methods

\section{What eco-methods do you apply?}

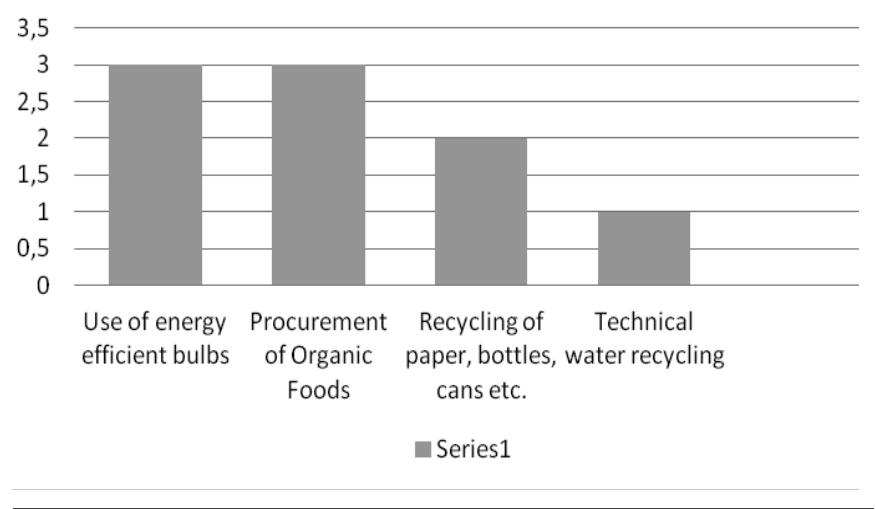

Source: Author's calculation

Significant activities and methods that reflect ecologically responsible operation of these accommodation facilities and significantly contribute to guest satisfaction regarding their stay in the facility relate to:

- the possibility of changing linen and towels at the request of a guest,

- the fact that groceries for the preparation of food and beverages are of organic origin,

- the applicationof eco - hygiene products,

- the fact that toilets, showers and taps operate with reduced water flow,

- the fact that waste materials (paper, PVC packaging and bottles, cans) are recycled, and

- Safe disposal of waste.

In this paper, in the segment of profitability indicators analysis, there is the analysis of the rate of Return on Assets (ROA), rate of Return on Equity (ROE) and total revenue per available room (TREVPAR) based on the data obtained from financial statements of three hotels in Serbia with the Green Key eco - label. After processing the downloaded data, indicators were obtained as follows in Table 1:

Table 1. Amounts of analyzed indicators

\begin{tabular}{lcccccc}
\hline & \multicolumn{2}{c}{ HOTEL A } & \multicolumn{2}{c}{ HOTEL B } & \multicolumn{2}{c}{ HOTEL C } \\
\hline $\begin{array}{l}\text { Business } \\
\text { year }\end{array}$ & 2017 & 2018 & 2017 & 2018 & 2017 & 2018 \\
\hline ROA & $10,69 \%$ & $0,00 \%$ & $11,65 \%$ & $9,38 \%$ & $0,00 \%$ & $0,00 \%$ \\
\hline ROE & $1,57 \%$ & $0,00 \%$ & $10,56 \%$ & $10,51 \%$ & $10,88 \%$ & $0,00 \%$ \\
\hline $\begin{array}{l}\text { TREVPAR } \\
\text { (in RSD) }\end{array}$ & 7247,69 & 7018,33 & 11209,62 & 11247,56 & 0,86 & 9408,94 \\
\hline
\end{tabular}

Source: Author's calculation 
The rate of Return on Assets (ROA) represents yield rate of total assets of an economic entity (Barjaktarović, et al. 2015). Based on the presented values of ROA indicators in Table 1 and Chart 2, it was observed that there were some changes in the value movements for this business indicator of the analyzed eco - friendly hotels.

Chart 2. Amounts of indicators ROA

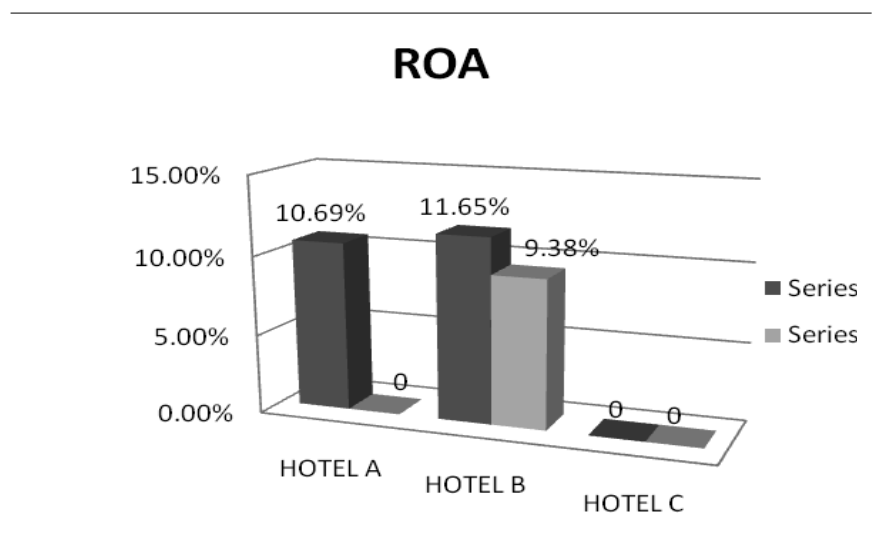

Source: Author's calculation

Namely, according to the data from financial business statements, hotel $\mathrm{C}$ operated at a loss in both business years, so it is impossible to calculate the return indicator on business assets for this economic entity. In 2017, Hotel A operated with a Business Profit and a Net Profit, so ROA indicator for this year is $10.69 \%$, which indicates that the economic entity has earned a yield of 10.69 dinars for every 100 RSD of funds employed. In 2018, Hotel A operated at a Business Loss and a Net Loss, so a zero value for ROA was obtained. A decrease in ROA value can occur when an economic entity enters a state of diminished ability to generate profits due to increased indebtedness (Radović \& Stanić, 2016).

According to the analyzed data, hotel $\mathrm{B}$ is the most stable one, since in both financial years it achieved Business profit and Net profit as the result of business period. However, it is in a slight decrease according to the data for the analyzed years. The ROA values for Hotel A are positive, i.e.the hotel achieved a yield of 11.65 dinars for 100 dinars offunds employed in 2017, while in 2018 a yield was 9.38 dinars.

The rate of Return on Equity (ROE) is a general indicator of the economic entity's success, bearing in mind that this indicator represents the rate of equity growth (Barjaktarović, et al. 2015).
Chart 3. Amounts of indicators ROE

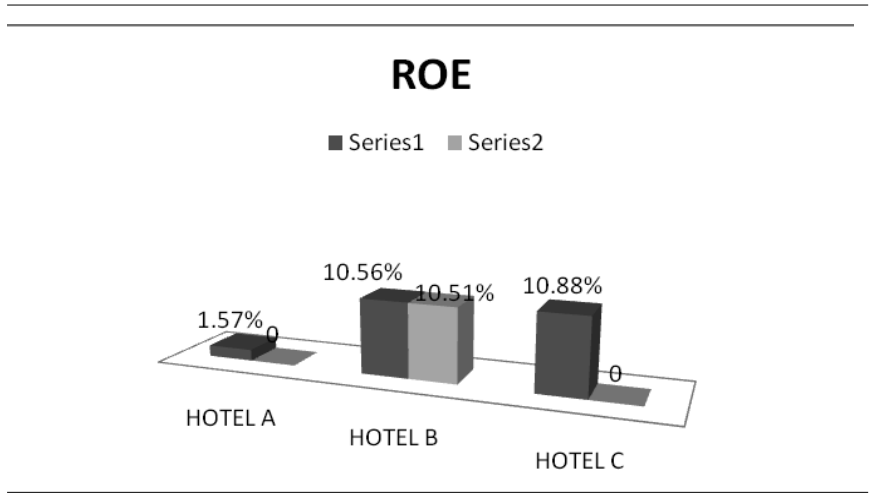

Source: Author's calculation

In Table 1 and Chart 3 it can be observed that there is a decrease in the value indicators of ROE. Namely, Hotel A and Hotel C had zero (0) values for this indicator in 2018, because these economic entities operated with Net Loss as a business result in the given year. In 2017, ROE for Hotel A was $1.57 \%$ and for Hotel C it was $10.88 \%$, which shows us that these economic entities had an increase in equity in that business year, i.e. Hotel A earned RSD 1.57 while Hotel C earned EUR 10.88 for every 100 RSD of funds employed. When it comes to Hotel B there was a slight decrease in the value of ROE. In 2017 it earned RSD 10.56 while in 2018 it earned RSD 10.51 for every RSD 100 of funds employed.

A decrease in the value of $\mathrm{ROE}$ indicators shows a reduced utilization of accommodation capacities of the analyzed economic entities, which leads to a decrease in the economic entity's earning capacity. Economic entities can increase the rate of return on equity by maximizing the rate of net profit and / or maximizing the ratio of equity turnover (Knežević, et al. 2019).

Total Revenue Per Available Room (TREVPAR) is a specific indicator for the hotel business activity and indicates the amount of revenue generated in relation to the used capacity of the accommodation facility during the business year (Bredgaard \& Pedersen, 2008).

Chart 4. Amounts of indicators TREVPAR

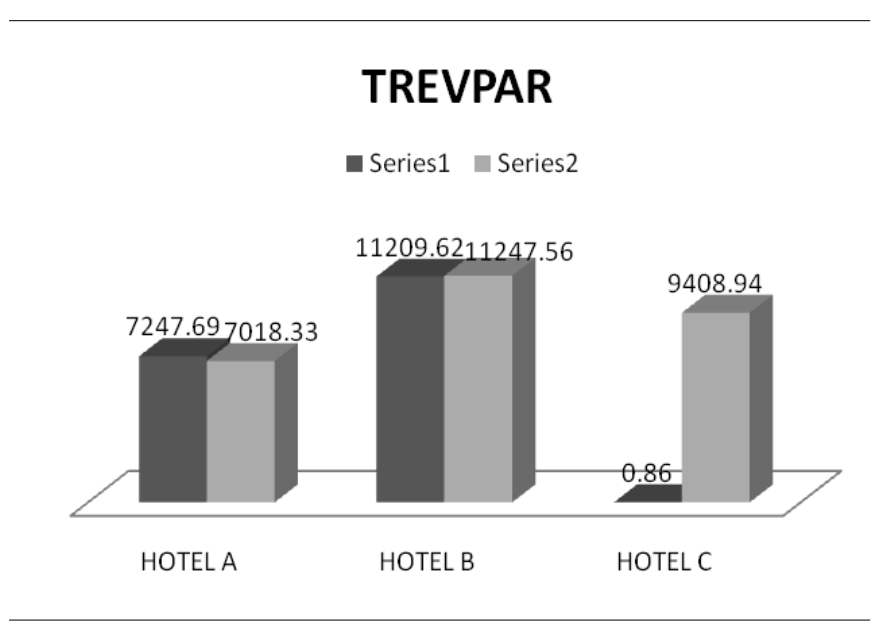

Source: Author's calculation 
TREVPAR values obtained in Chart 4 indicate that there was a slight decline in Hotel A revenue per available room in 2018 compared to 2017, which is associated with a decline in business and a net loss as a business result for year 2018. There was a slight increase in the value of indicators in the business of Hotel B, so there was an increase of RSD 37.94 in revenue per available room in 2018 compared to 2017. Hotel C started operating in 2017 and according to the data calculation it generated a minimal income per available room. However, the revenue per available room was 9408, 94 dinars in 2018.

\section{CONCLUSION}

Considering the analysis of results of the aforementioned ecohotels, we can see that the management shows business efforts and applies standards and criteria in the development of ecologically friendly, responsible and sustainable business and can be an example to the hotels that do not operate in this way. Profitability indicators obtained in certain periods of business are directly related to eco-activities, but in most cases external factors affect business processes and business results. It is important to note that investments in new technologies in the hotel business contribute to energy and eco - efficiency and affect cost management in business, leading to increased business results. At the same time, the quality of services and the security of guests are being improved, which leads to their increased satisfaction and increased competitiveness in the tourism market, especially bearing in mind the characteristics and understanding of the so - called "Tourists of the future".

The development of environmental awareness and the ongoing education of employees are very important bearing in mind that hotel employees are the "reflection of the company" and the central part of the owner / management's realization of business ideas.

\section{REFERENCES}

1. Barjaktarović L., Jović Z., Milojević M. (2015). Poslovne finansije. Beograd: Univerzitet Singidunum, p.147-148

2. Barjaktarović D., Barjaktarović L., Pindžo R. (2017). Osvrt na značaj energetske efikasnosti u hotelijerstvu. Turističko poslovanje, No 19, p 37-43

3. Bredgaard O., Pedersen M. (2008). Financial Management in a service perspective. Copenhagen: Academica, p.47

4. Camillari M.A. (2014). Advancing the Sustainable Tourism Agenda trough Strategic CSR Perspectives. Tourism Planning \& Development, 11(1). p 42-56

5. Dražić G. (2018). Održivi turizam. Beograd: Univerzitet Singidunum, p. 23
6. Kirk D. (1995). Environmental management in hotels. International Journals of Contemporary Hospitality Management, 7(6), p 3-8

7. Knežević G., Stanišić N., Mizdraković V. (2019).Analiza finansijskih izveštaja. Beograd: Univerzitet Singidunum, p. 185

8. Measuring Sustainable Tourism, Making Tourism More Sustainable - A Guide for Policy Makers. (2005). Madrid: UNEP\&UNWTO

9. Radović N., Stanić N. (2016). Analiza pokazatelja rentabilnosti poslovanja hotelskih preduzeća, FINIZ 2016. Beograd: Univerzitet Singidunum, p 171-174

10. https://www.greenkey.global/join-green-key, date of access 16.09.2019.

11. https://www.fee.global/, date of access 16.09.2019.

12. https://www.statista.com/statistics/247264/totalrevenue-of-the-global-hotel-industry/, date of access 20.09.2019. 